\title{
Finite Element Based Life Prediction of a New Free Piston Linear Generator Engine Mounting
}

Md. Mustafizur Rahman, Ahmad Kamal Ariffin, Nordin Jamaludin and Che Hasan Che Haron

\author{
Computational and Experimental Mechanics Group \\ Department of Mechanical and Materials Engineering \\ Universiti Kebangsaan Malaysia \\ 43600 UKM Bangi, Selangor, \\ Malaysia \\ Phone:03-8921 6012; Fax:03-8921 6040 \\ E-mail:mustafiz@eng.ukm.my
}

Received Date: $29^{\text {th }}$ August 2006 Accepted Date: $7^{\text {th }}$ March 2007

\begin{abstract}
This paper presents the finite element based fatigue life prediction of a new free piston linear generator engine mounting. The objective of this paper is to assess the critical fatigue locations on the component due to loading conditions and also assess the damage tolerance design. This paper shows the effect of mean stress and the probabilistic nature of fatigue on the fatigue life. The finite element modeling and analysis have been performed using computer-aided design and finite element analysis software packages and the fatigue life prediction was carried out using commercial fatigue codes. Stress-life approach and strain-life approach are applied to predict the fatigue life of the free piston linear engine mounting. The result is a life contour, showing how long each area of a mounting will survive under defined loading conditions. The results are expected to show contour plots of fatigue life, and damage histogram at the worst or most damaging case. This paper shows the comparison between the stress-life approach and strain-life approach. From the results, it can be concluded that Morrow mean stress correction method has been found to give the most conservative results for strain-life method. SAE 1045-450-QT and SAE 1045-595-QT materials are considered in this study. It can be also seen that SAE 1045-595-QT material gave consistently higher life than SAE 1045-450-QT material for all loading conditions for both methods.
\end{abstract}

Keywords: Fatigue life, finite element, stress-life, strain-life, linear generator engine.

\section{ABSTRAK}

Kertas ini membentangkan ramalan hayat lesu berdasarkan kaedah unsur terhingga bagi pencagak enjin penjana linear omboh bebas yang baru. Objektif kertas ini adalah untuk menilai kedudukan lesu kritikal komponen disebabkan oleh keadaan beban dan menilai reka bentuk had terima musnah. Dalam kertas kerja ini menunjukkan kesan tegasan min dan tabii kebarangkalian lesu. Permodelan dan analisis kaedah unsur terhingga telah dijalankan menggunakan reka bentuk terbantu komputer dan pakej perisian analisis unsur terhingga manakala ramalan hayat lesu dijalankan dengan kod lesu komersial pendekatan hayat-tegasan dan pendekatan permalaan retak digunakan bagi meramal hayat lesu pencagak engin linear omboh bebas. 
Keputusan kontur lesu menunjukkan jangka hayat sesuatu kawasan di pencagah di bawah keadaan beban yang tertentu. Keputusan juga menunjukkan plot kontur hayat lesu dan histogram musnah bagi kes yang paling teruk. Kertas kerja ini menunjukkan perbandingan antara pendekatan hayat-tegasan dan pendekatan hayat-terikan. Dari keputusan dapat disimpulkan kaedah pembetulan tegasan min Morrow memberi keputusan yang paling konservatif dari kaedah hayat-terikan. Bahan SAE 1045-450-QT dan SAE 1045-595-QT dipertimbangkan dalam kajian ini. Didapati bahan SAE 1045-595-QT sentiasa mempunyai hayat lebih lama berbanding dengan SAE 1045-450-QT untuk semua beban dan kedua-dua kaedah.

Kata kunci: Hayat lesu, unsur terhingga, hayat-tegasan, hayat-terikan, enjin penjana linear.

\section{INTRODUCTION}

A free piston linear generator integrates a combustion engine and a linear electrical machine into a single unit without a crankshaft. This provides an unconventional solution for series hybrid vehicles and distributes/ emergency power units (Zhang et al. 1997; Blarigan 2000; Goertz \& Peng 2000; Arshad et al. 2002a; Arshad et al. 2003 \& Cosic et al. 2003). Blarigan (2000) developed a free piston alternator in the $30 \mathrm{~kW}$ range. He implemented a nonconventional combustion technique known as homogeneous charge compression ignition $(\mathrm{HCCl})$. The Schematic diagram of free piston linear engine is shown in Figure 1. The absence of the crankshaft has benefits in the reliability, efficiency, fuel consumption, and environmental emissions (Arshad et al. 2004). The used of free piston generators to produce electricity with the Stirling engines has been around for quite some times (Dhar \& Dochat 1989). However, applications with the internal combustion engines are relatively new. Although many patents have been reported (Gray 2003; Berlinger et al.2004; Hofbauer et al. 2005; Schaeffer 2005 \& Wood 2005) the reported research work is rather sparse (Zhang et al. 1997; Blarigan 2000; Goertz \& Peng 2000).
Arshad et al. (2004) investigated the use of transverse flux machines in a free piston generator. A free piston generator integrates a combustion engine and a linear electrical machine to provide benefits in terms of efficiency, emissions and reliability. In this study, authors concentrated only on the electric generator. The past research at West Virginia University of United States of America demonstrated the stable operation of a free piston engine generator by Famouri et al.(1999).Spark-ignited linear engine and an air-core linear alternator system manage to produce 500W of output power (Arshad et al. 2002b).The engine system was based on a pair of opposed cylinders, operating under a two-stroke cycle. For the linear alternator, moving permanent magnets are located within a series of stationary coils for voltage induction.

In the two-stroke free piston engine (Arshad et al.2002c) two horizontally opposed pistons are mounted on a connecting rod, which is allowed to oscillate between the two end-mounted cylinders. Most of the previous studies (Aichlmayr 2002 \& Arshad et al. 2002a, 2002b, 2002c, 2003, 2004) which are related to the engine, the combustion occurred in both cylinders, in order to get the linear movement of the piston. For this linear engine, crank and camshaft will be

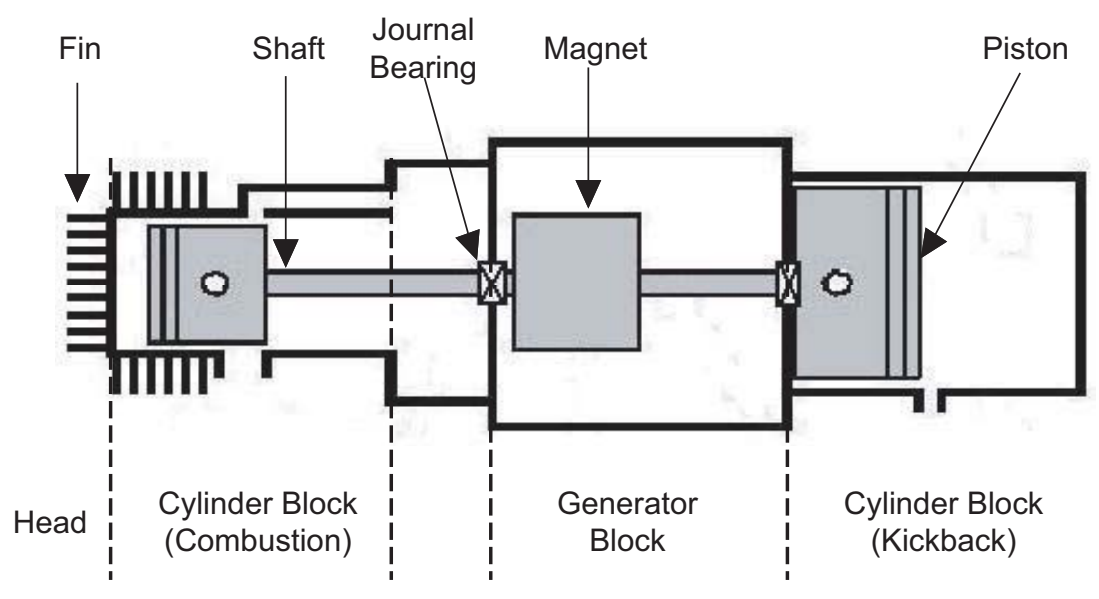

FIGURE 1. Free Piston Linear Engine 
eliminated and there was no rotary movement involved. Additionally, the linear system of the engine should prove to be more efficient as the frictional losses associated with the crack and rod bearings are eliminated. However, in previous study by Aichlmayr (2002) determined that a single piston engine with rebound device and the unbalanced situation. These need to be encounter for this new free piston generator engine.

Mounting of the two-stroke free piston engine structures is commonly fatigue loading. Fatigue durability has long been important issues in the design of free piston linear generator engine structures. In engineering applications, the purpose of fatigue research consists of predicting engine using total life and strain-life methods, and to investigate the effect of mean stress on fatigue life and also the probabilistic nature of fatigue on the $S-N$ curve via the design criteria.

\section{FINITE ELEMENT BASED FATIGUE ANALYSIS}

The fatigue analysis is used to compute the fatigue life at one location in a structure. For multiple locations the process is repeated using geometry information applicable for each location. Necessary inputs for the fatigue analysis are shown in Figure 2. The three input information boxes are descriptions of the material properties, loading history and local geometry. All of these inputs are discussed in the following sections.

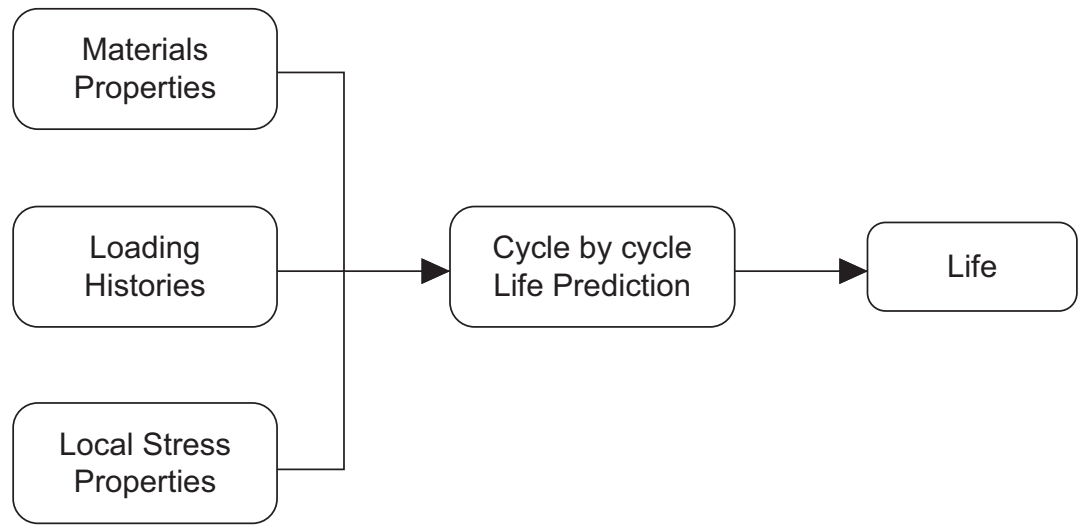

FIGURE 2. Fatigue analysis prediction strategy

the fatigue life of structures, increasing fatigue life and simplifying fatigue tests especially fatigue tests of full-scale structures under a random load spectrum. The fatigue life of an engineering structure principally depends upon that of its critical structure members and also depends on the nature of loading, type of the materials, vibration effects and invariants i.e.in automotive the road profiles etc. There is an increasing interest within the internal combustion engine industry in the ability to produce designs that are strong, reliable and safe, whilst also light in weight, economic and easy to produce. These opposing requirements can be satisfied by analytically optimizing components of linear generator engine. In the engine system design, the mounting structure is among the most critical parts. Numerical techniques are necessary to simulate the physical behavior and to evaluate the structural integrity of the different designs.

The objectives of the current study were to calculate the fatigue life for a mounting of linear
- Material information - cyclic or repeated material data based on constant amplitude testing.

- Load histories information - measured or simulated load histories applied to a component. The term loads is used to represent forces, displacements, accelerations, etc.

- Geometry information- relates the applied load histories to the local stresses and strains at the location of interest. The geometry information is usually derived from FE results.

An integrated FE based durability analysis is considered to be a complete analysis of an entire component. Fatigue life can be estimated for every element in the finite element model, and contour plots of life or damage plotted in a similar way to stresses. Geometry information is provided by FE results for each load case applied 


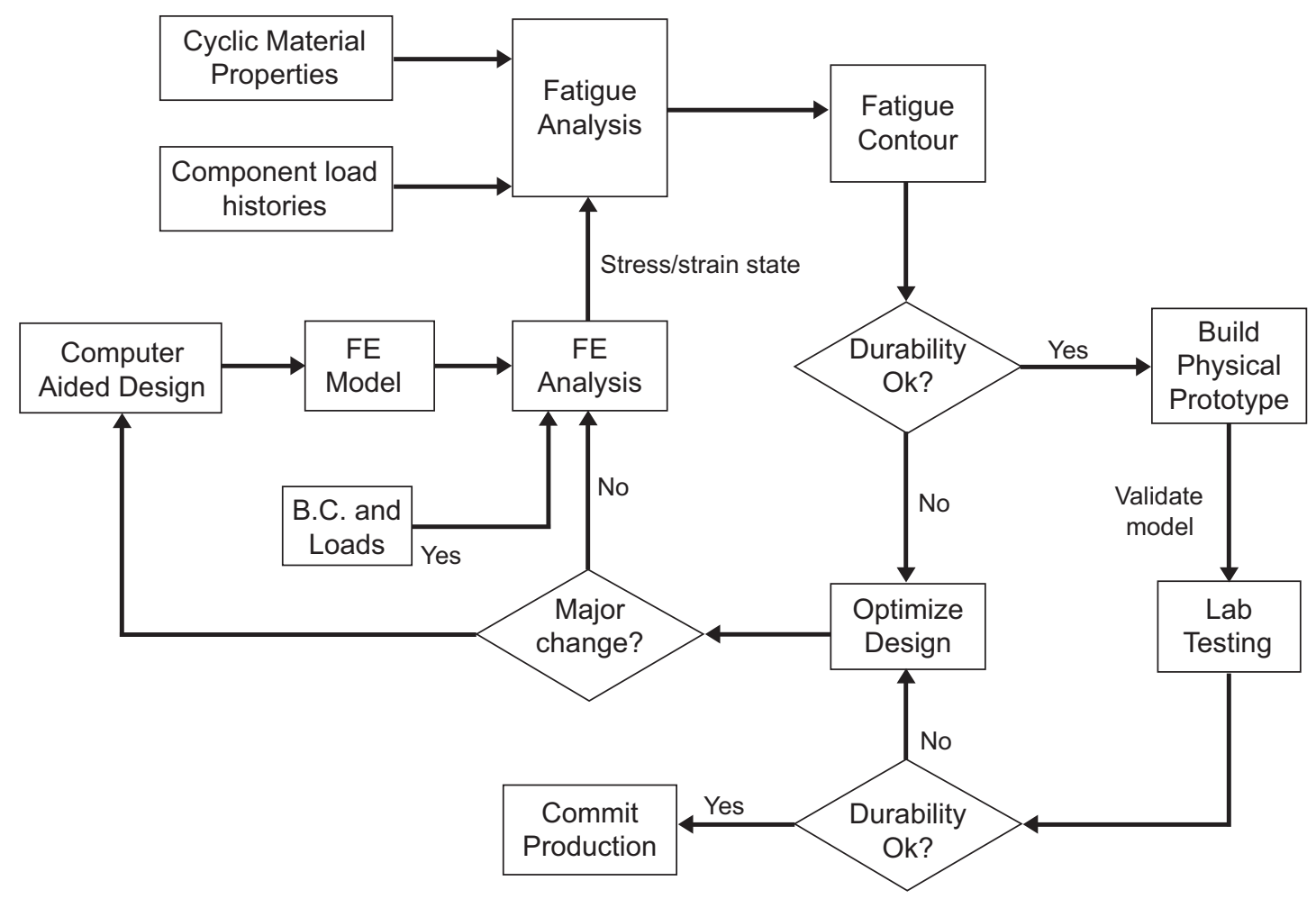

FIGURE 3. Integrated finite element based fatigue life prediction analysis

independently, i.e. the FE results define how an applied load is transformed into a stress or strain at a particular location in the component. Appropriate material data are also provided for the desired fatigue analysis method. This schematic diagram of the process is shown in Figure 3.

\section{FATIGUE ANALYSIS METHODS}

Fatigue analyses can be undertaken by using of one of three basic methodologies, i.e. the stress-life approach, the strain-life approach and crack propagation approach. The stress-life approach was first applied over a hundred years ago (Wöhler 1867) and considers nominal elastic stresses and how they are related to life. The strain-life approach, which evolved some fifty years ago, considers elastic-plastic local stresses and strains. It represents a more fundamental approach and is used to determine the number of cycles required to initiate a small engineering cracks. Crack propagation or linear elastic fracture mechanics (LEFM) approach is used to predict how quickly pre-existing cracks grow and also to estimate how many loading cycles are required to grow these to a critical size when catastrophic failure would occur. First two methods are used in this paper and briefly discussed these two methods in the following sections.
The fatigue stress-life $(S-N)$ approach is typically used for the life prediction of components subjected to high cycle fatigue, where stresses are mainly elastic. This approach emphasises nominal stresses rather than local stresses. It uses the material stress-life curve and employs fatigue notch factors to account for stress concentrations, empirical modification factors for surface finish effects, and analytical equations such as modified Goodman and Gerber equation to account for mean stress effects. The modified Goodman and Gerber equations are given by Equations (1) and (2) respectively.

$$
\begin{aligned}
& \frac{\sigma_{a}}{S_{e}}+\frac{\sigma_{m}}{S_{u}}=1 \\
& \frac{\sigma_{a}}{S_{e}}+\left(\frac{\sigma_{m}}{S_{u}}\right)^{2}=1
\end{aligned}
$$

where $\sigma_{a^{\prime}} S_{e_{1}} \sigma_{m_{1}}$ and $S_{u}$ are the alternating stress in the presence of mean stress, alternating stress for equivalent completely reversed loading, the mean stress and the ultimate tensile strength, respectively. The typical representation of these mean stress correction methods is shown in Figure 4.

The Basquin (1910) showed that alternating stress versus number of cycles to failure $(S-N)$ in 


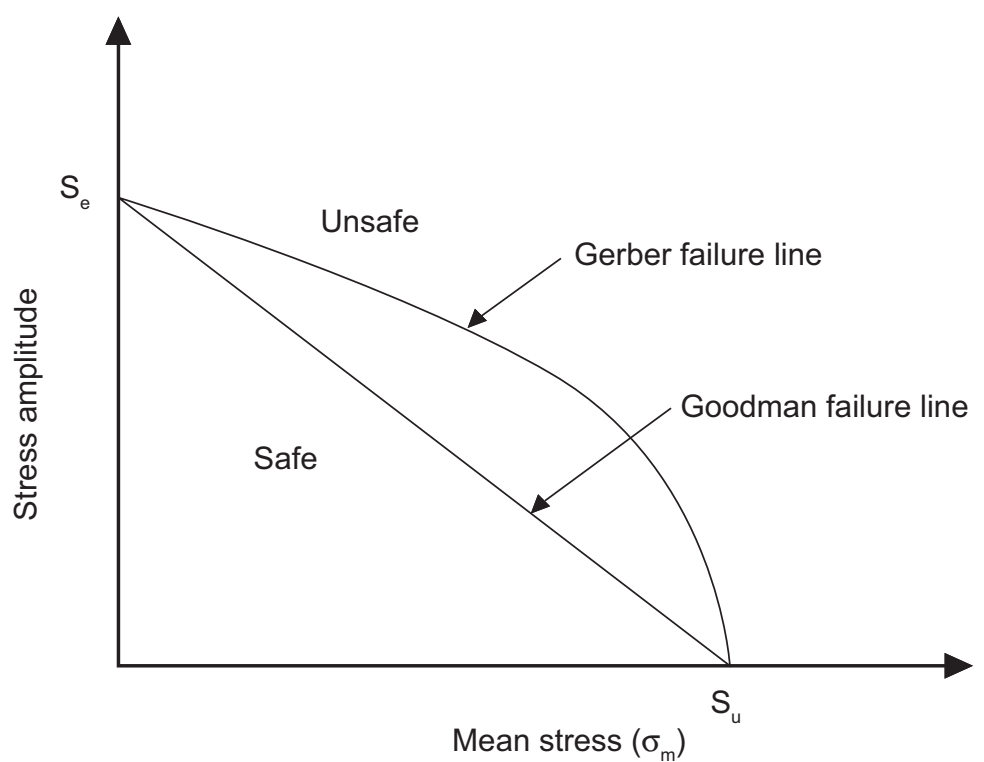

FIGURE 4. Comparison of the mean stress correction method

TABLE 1. Mechanical properties of the materials (Boardman 1982)

\begin{tabular}{lcc}
\hline \multicolumn{1}{c}{ Properties } & \multicolumn{2}{c}{ Materials } \\
& SAE 1045-450-QT & SAE 1045-595-QT \\
\hline Yield strength, YS (MPa) & 1515 & 1860 \\
Ultimate Tensile Strength, UTS, (MPa) & 1584 & 2239 \\
Elastic Modulus, E (MPa) & 207000 & 207000 \\
Fatigue Strength Coefficient, $\sigma_{f}^{\prime}$ & 1686 & 3047 \\
Fatigue Strength Exponent, $b$ & -0.06 & -0.1 \\
Fatigue Ductility Exponent, $c$ & -0.83 & -0.79 \\
Fatigue Ductility Coefficient, $\varepsilon_{f}^{\prime}$ & 0.79 & 0.13 \\
Cyclic Strain hardening Exponent, $n^{\prime}$ & 0.09 & 0.1 \\
Cyclic Strength Coefficient, $k^{\prime}$ & 1874 & 3498 \\
\hline
\end{tabular}

the finite life region could be represented as a log-log linear relationship.The Basquin equation was then used to obtain the fatigue life using the material properties listed in Table 1. The $S-N$ approach uses to estimate the fatigue life for torsion or combined loading by determining an equivalent axial stress (Zoroufi \& Fatemi 2004) using one of the common failure criteria such as Tresca, von Mises, or maximum principal stress. The $S-N$ equation is mathematically given by

$$
S_{e}=\sigma_{f}^{\prime}\left(2 N_{f}\right)^{b}
$$

where $S_{e^{\prime}} \sigma_{f}^{\prime}, 2 N_{f}$ and $b$ are the stress amplitude, the fatigue strength coefficient, the reversals to failure, and the fatigue strength exponent, respectively.

An important aspect of the fatigue process is plastic deformation. Fatigue cracks initiate from the plastic straining in localized regions. Therefore,cyclic strain-controlled fatigue method can better characterize the fatigue behaviour of the materials than cyclic stress-controlled fatigue. Particularly in notched members, where significant localized plastic deformation is often present. In the strain-life approach the plastic strain or deformation is directly measured and quantified. The stress-life approach does not account for plastic strain. One of the main advantages of this method is that it accounts for changes in local mean and residual stresses.

When the load history contains large overloads, significant plastic deformation can exist, particularly at stress concentrations, and the load sequence effects can be significant. In these cases, the strain-life approach is generally superior to the stress-life approach for fatigue life prediction analysis. However, when the load 
levels are relatively low such that the resulting strains are mainly elastic, the strain-life and stress-life approaches usually result in similar predictions.

The strain-life approach to fatigue problems is widely used at present, especially when the linear generator engine are started or stopped then it is subjected to a very high stress range. The fatigue strain-life approach involves the techniques for converting load history, geometry, and material properties (monotonic and cyclic) input into a fatigue life prediction. The operations involved in the prediction must be performed sequentially. First, the stress and strain at the critical site are estimated, and rainflow cycle counting method (Matsuishi \& Endo 1968) is then used to reduce the load-time history based on the peak-valley sequential. The next step is to use the finite element method to convert a reduced load-time history into a strain-time history and calculate the stress and strain in the highly stressed area. Then the strain-life methods are employed for predicting fatigue life. Following this, the simple linear damage hypothesis proposed by Palmgren
(1927) and Miner (1945) is used to accumulate the fatigue damage. Finally, the damage value for all cycles are summed until a critical damage sum (failure criteria) is reached.

In order to perform the fatigue analysis and to implement the stress-strain approach in complex structures, Conle and Chu (1997) used strain-life results which is simulated using the three dimensional (3D) models to assess fatigue damage. After the complex load history was reduced to an elastic stress history for each critical element, a neuber plasticity correction method was used to correct for plastic behaviour. Elastic unit load analysis, using strength of material and an elastic finite element analysis (FEA) model combined with a superposition procedure of each load point's service history was proposed.Savaidis (2001) verified the local strain approach for durability evaluation. In this study, it was observed that the local strain approach using the Smith-Watson-Topper (SWT) strainlife model is able to represent and to estimate many factors explicitly. These include mean stress effects, load sequence effects above and below

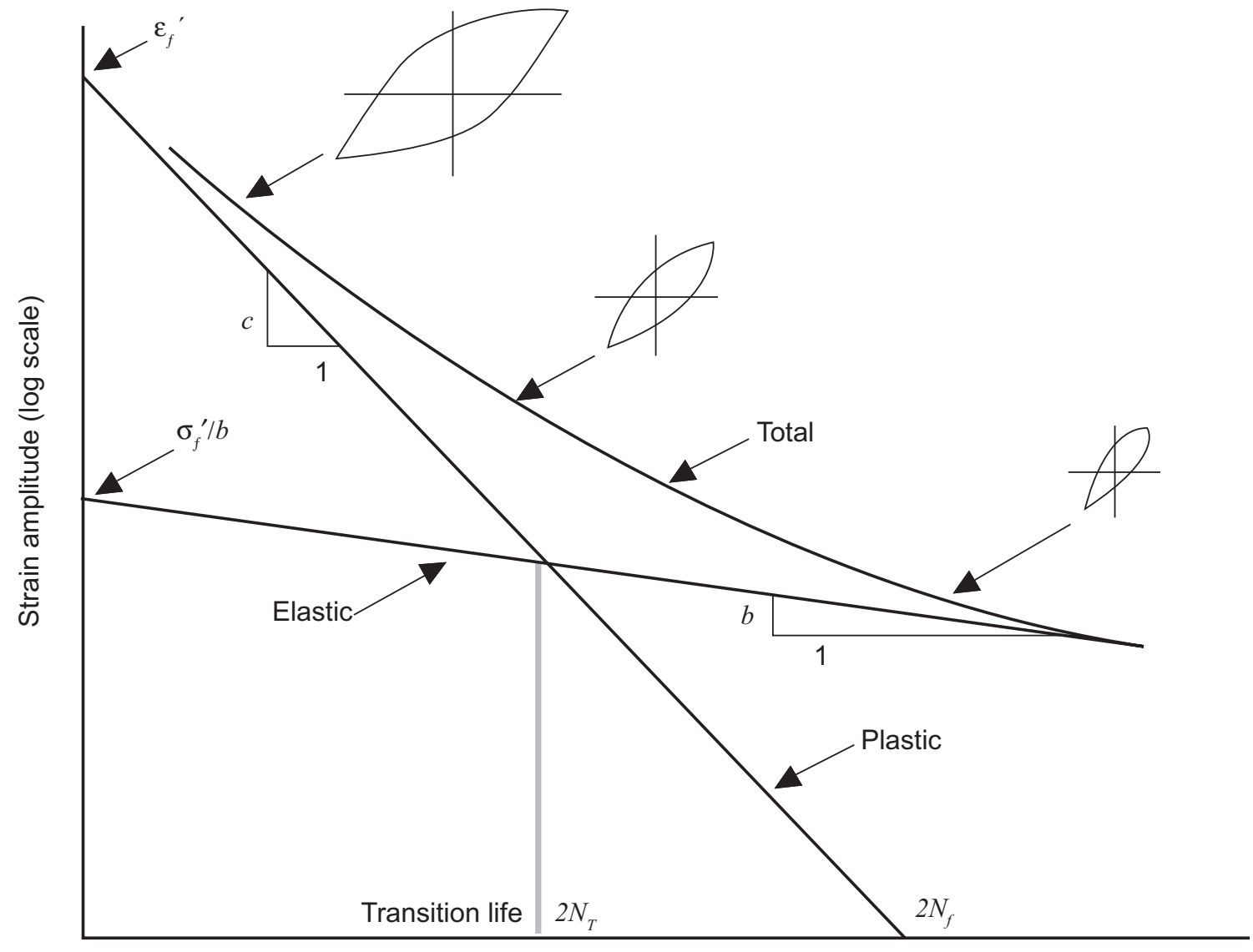

Reversal to failure (log scale)

FIGURE 5. Typical total strain-life curve 
the endurance limit, and manufacturing process effects such as surface roughness and residual stresses and also stated in the book by Juvinall (1991).

The fatigue resistance of metals can be characterized by a strain-life curve. These curves are derived from the polished laboratory specimens tested under completely reversed strain control.The relationship between the total strain amplitude, $\Delta \varepsilon / 2$, and reversals to failure, $2 \mathrm{~N}_{f}$ , can be expressed in the following form (Coffin 1954 \& Manson 1953). Figure 5 represents the typical total strain-life curves.

$$
\frac{\Delta \varepsilon}{2}=\frac{\sigma_{f}^{\prime}}{E}\left(2 N_{f}\right)^{b}+\varepsilon_{f}^{\prime}\left(2 N_{f}\right)^{c}
$$

where, $\mathrm{Nf}$ is the fatigue life; $\sigma_{f}^{\prime}$ is the fatigue strength coefficient; $E$ is the modulus of elasticity; $b$ is the fatigue strength exponent; $\varepsilon_{f}^{\prime}$ is the fatigue ductility coefficient; and $\mathrm{c}$ is the fatigue ductility exponent.Morrow (1968) suggested correction model. It is mathematically defined as:

$$
\sigma_{\max } \varepsilon_{a} E=\left(\sigma_{f}^{\prime}\right)^{2}\left(2 N_{f}\right)^{2 b}+\sigma_{f}^{\prime} \varepsilon_{f}^{\prime} E\left(2 N_{f}\right)_{(6)}^{b+c}
$$

where, $\sigma_{\max }$ is the maximum stress, and $\varepsilon_{a}$ is the strain amplitude.

\section{MATERIAL INFORMATION}

The material data is one of the major input is the definition of how a material behaves under the cyclic loading conditions it typically experiences during service operation. Cyclic material properties are used to calculate elasticplastic stress strain response and the rate at which fatigue damage accumulates due to each fatigue cycle. The materials parameters required depend on the analysis methodology being used. Normally, these parameters are measured experimentally and available in various
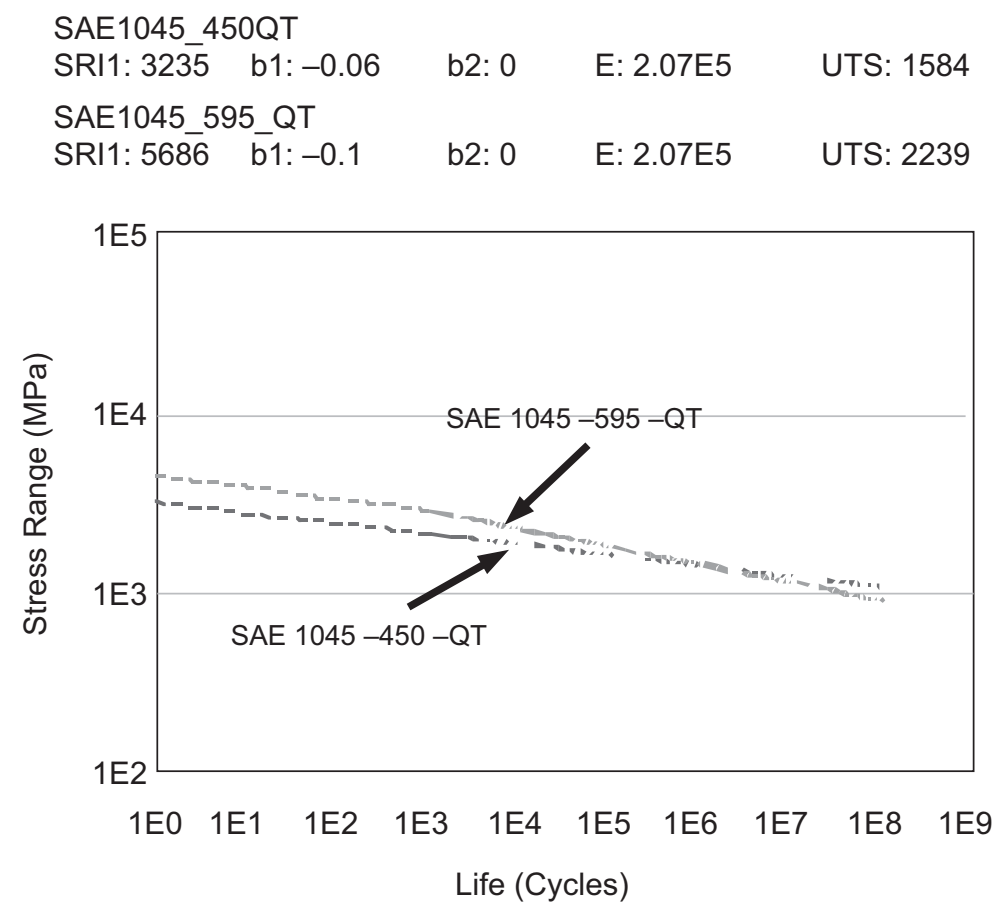

FIGURE 6. Stress-life $(S-N)$ plot

that mean stress effects could be considered by modifying the elastic term in the strain-life equation by mean stress, $\sigma_{m}$.

$$
\varepsilon_{a}=\frac{\sigma_{f}^{\prime}-\sigma_{m}}{E}\left(2 N_{f}\right)^{b}+\varepsilon_{f}^{\prime}\left(2 N_{f}\right)^{c}
$$

Smith et al. (1970) introduced another mean stress model which is called SWT mean stress handbooks. Two different materials were used for this component, SAE 1045-QT and SAE 1045595-QT. Now there will be discussed briefly their characteristics in this section. Figure 6 shows a comparison of the two materials with respect to $\mathrm{S}-\mathrm{N}$ behaviour. It can be seen that these curves exhibit different life behaviour depending on the stress range experienced. From the figure, 

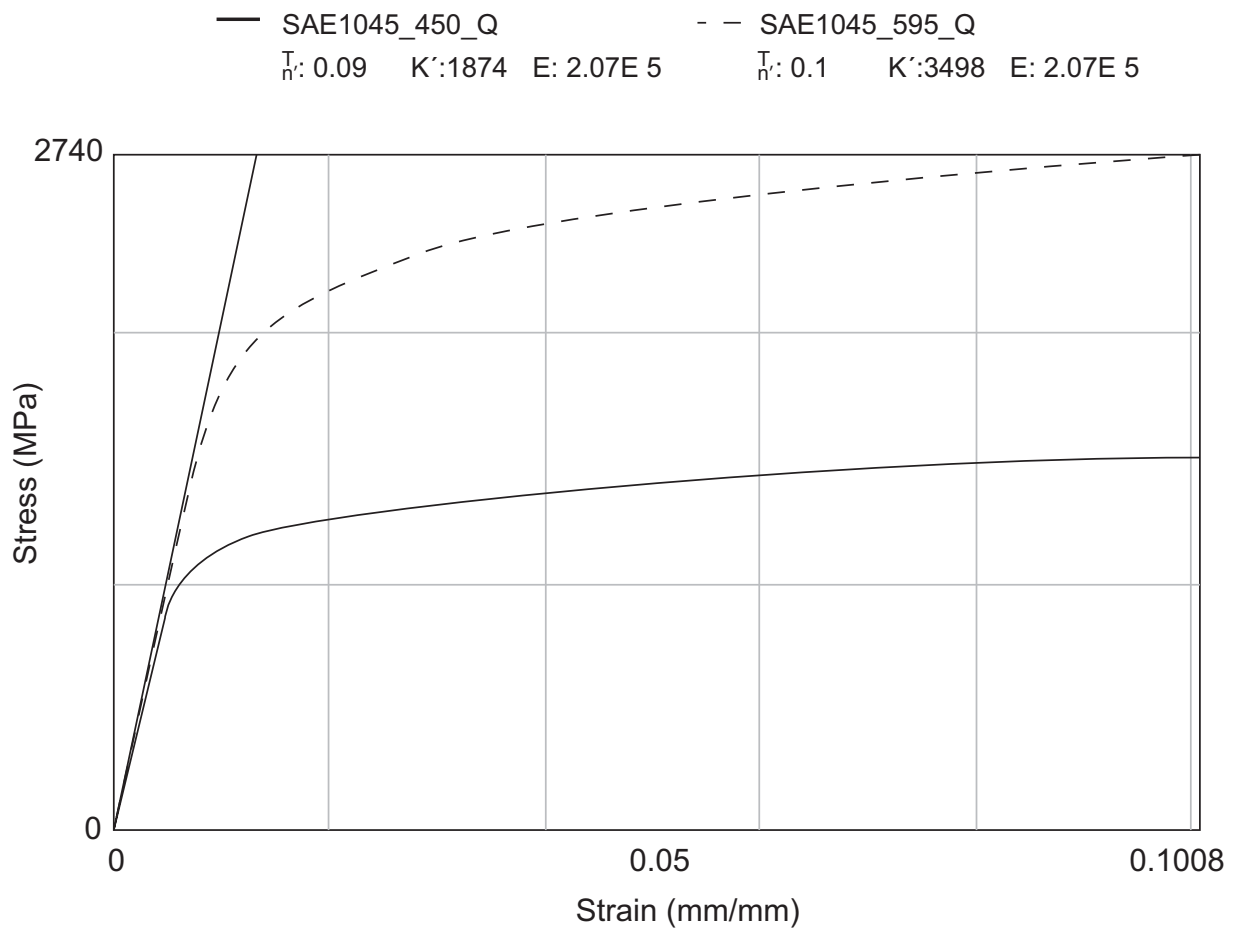

FIGURE 7. Cyclic stress-strain plot.

it can be seen that in the long life area (high cycle fatigue), the difference is lower while in the short life area (low cycle fatigue), the difference is higher. Figure 7 shows the cyclic stress-strain curves of these two materials. It can be seen how these two materials behave under cyclic loading conditions and also shows how they behave relative to one another. It can be seen that SAE 1045-595-QT is much higher strength steel with its yield point well above that of SAE 1045-450-QT.

Figure 8 represents the strain-life curves indicating that different fatigue life behaviour can be observed for both materials. Figure 8 is plotted
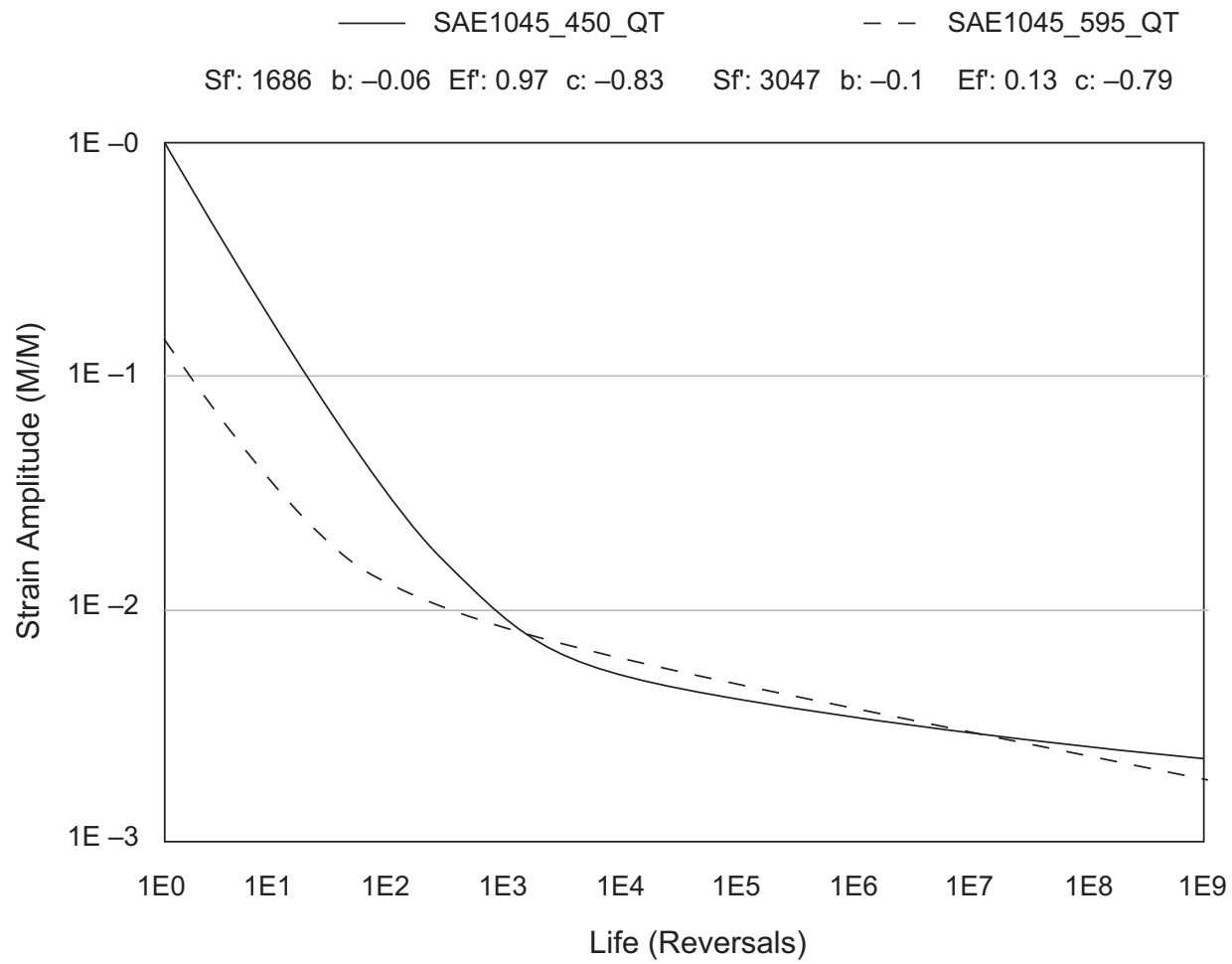

FIGURE 8. Strain-life plot 
- - SAE1045_450_QT

Sf': 1686 b: -0.06 Ef': 0.97 c: -0.83
SAE1045_595_QT

Sf': 3047 b: $-0.1 \quad E f ': 0.13$ c: -0.79

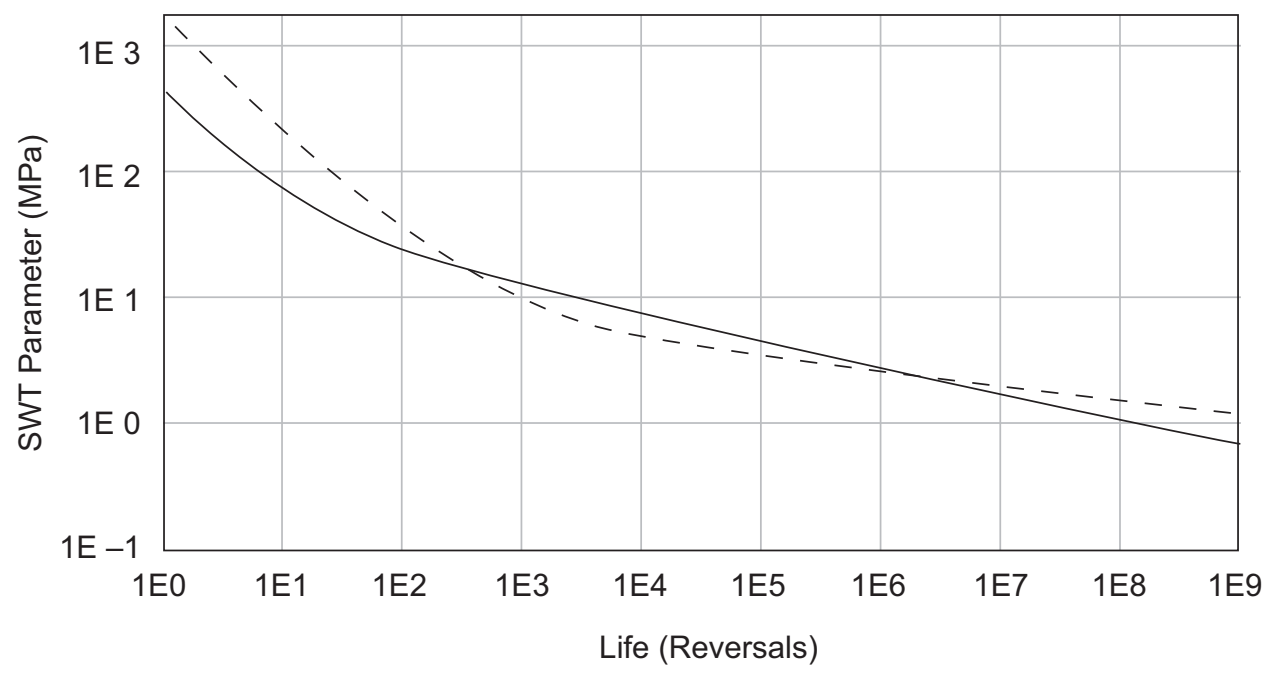

FIGURE 9. SWT strain-life plot

- - SAE1045_450_QT

Sf': 1686 b: -0.06 Ef': 0.97 c: -0.83
SAE1045_595_QT

Sf': 3047 b: $-0.1 \quad$ Ef': 0.13 c: -0.79

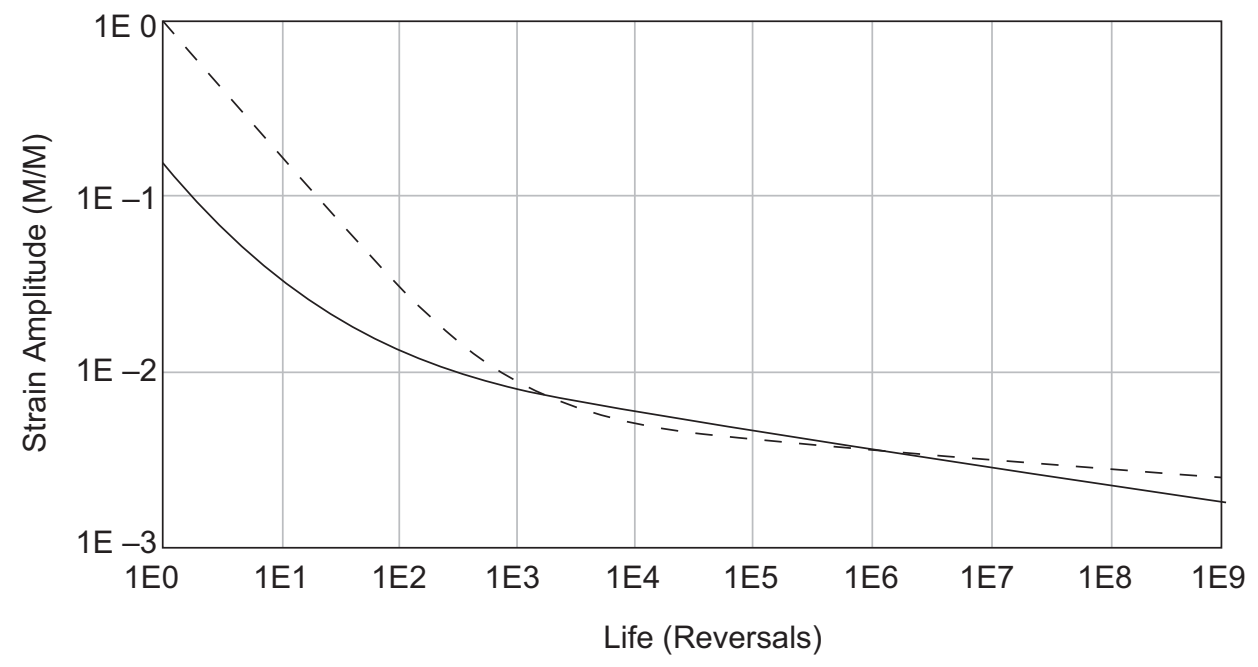

FIGURE 10. Morrow's strain-life plot

based on the Coffin-Manson relationship. From the figure, it can also be seen that in the long life area (high cycle fatigue) the difference is lower while in the short life area (low cycle fatigue) the difference is higher. Figures 9 and 10 also show that another strain-life curves those are based on SWT and Morrow models respectively.

\section{LOADING INFORMATION}

Another major input to finite element based fatigue analysis. The component was loaded with three random time histories, corresponding to typical histories for transmission, suspension and bracket components at different load levels. The detailed information about these histories was contained in the literature (Tucker \& Bussa 1977). These histories were scaled to two peak strain levels and used as full-length histories. In addition, a random history including many spikes was selected for simulation of spike removal. Raw histories are shown in Figure 11. The terms of SAETRN, SAESUS, and SAEBRAKT represent the load-time history for the transmission, suspension, and bracket respectively. The considered loadtime histories are based on the SAE's profile. The abscissa uses the time in seconds. 

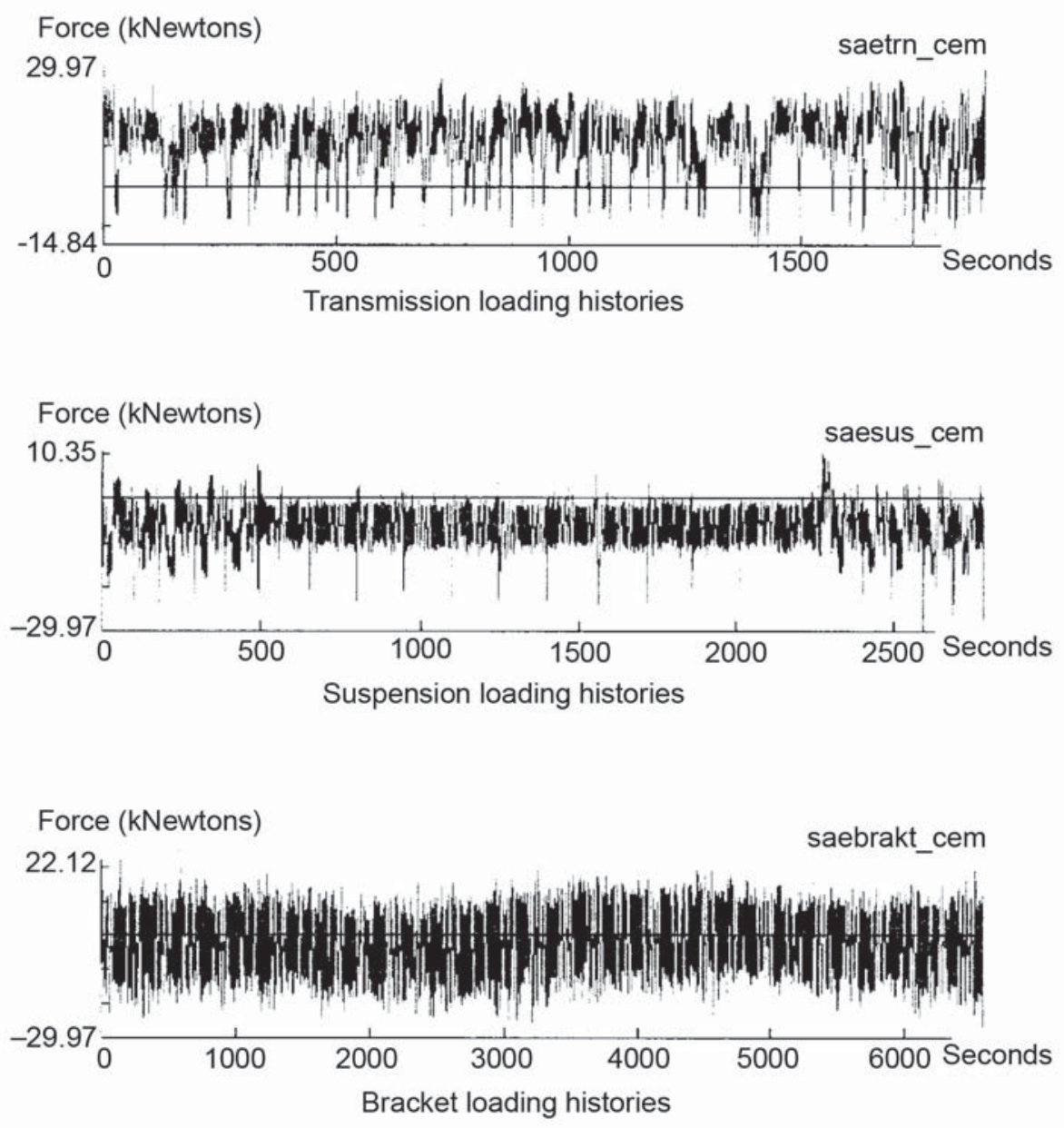

FIGURE 11. Load-time histories

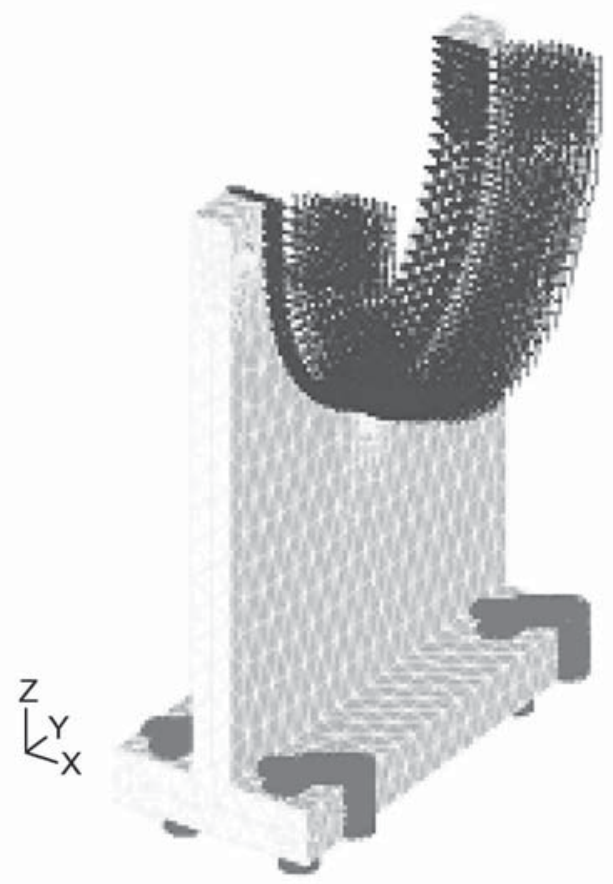

FIGURE 12. Geometry, loading, constraints and finite element model 


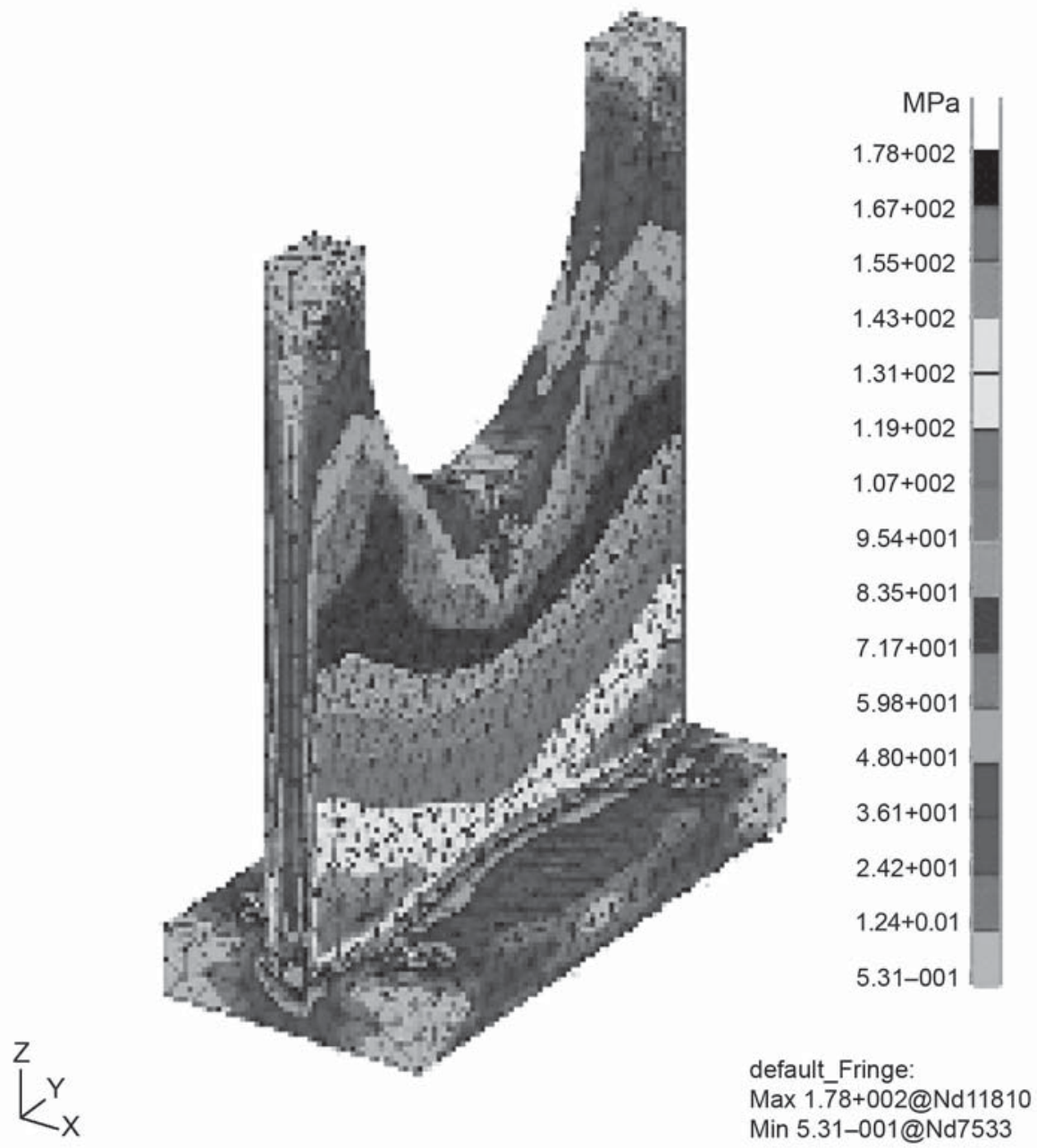

FIGURE 13. Von Mises stresses distribution contours

\section{FINITE ELEMENT ANALYSIS}

Three-dimensional model of linear generator engine mounting was developed using the in CATIA $^{\circledR}$ software. A parabolic tetrahedron element was used for the solid mesh. Sensitivity analysis was performed in order to obtain the optimum element size. These analyses were performed iteratively at different element lengths until the solution obtained appropriate accuracy. Convergence of stresses was observed, as the mesh size was successively refined. A total of 35415 elements and 66209 nodes were generated at $0.20 \mathrm{~mm}$ element length. The constraints were applied on the bolthole for all six degree of freedom. The objective of the FEA was to investigate stresses of mounting of free piston engine. Figure 12 shows the geometry, loading and boundary conditions used for the FEA analysis of linear generator engine mounting. From the resulting stress contours, the state of stress can be obtained and consequently used for uniaxial life predictions.

\section{RESULTS AND DISCUSSION}

The linear static finite element analysis was performed using MSC.NASTRAN ${ }^{\circledR}$ finite element software. The equivalent von Mises stress contours and critical locations are presented in Figure 13. The bolt holes and fillet areas were found to be areas of high stresses. The von Mises equivalent stresses and strains are used for subsequent fatigue life analysis and comparisons. From the FEA results, the maximum von Mises stresses of $178 \mathrm{MPa}$ at node 11810 was obtained. The fatigue life of the free piston engine mounting is obtained using variable amplitude loading conditions by means of SAETRN, SAESUS and SAEBRAKT data set. The fatigue life prediction results of mounting corresponding to $99.5 \%$ reliability value are shown in Figure 14 and it 


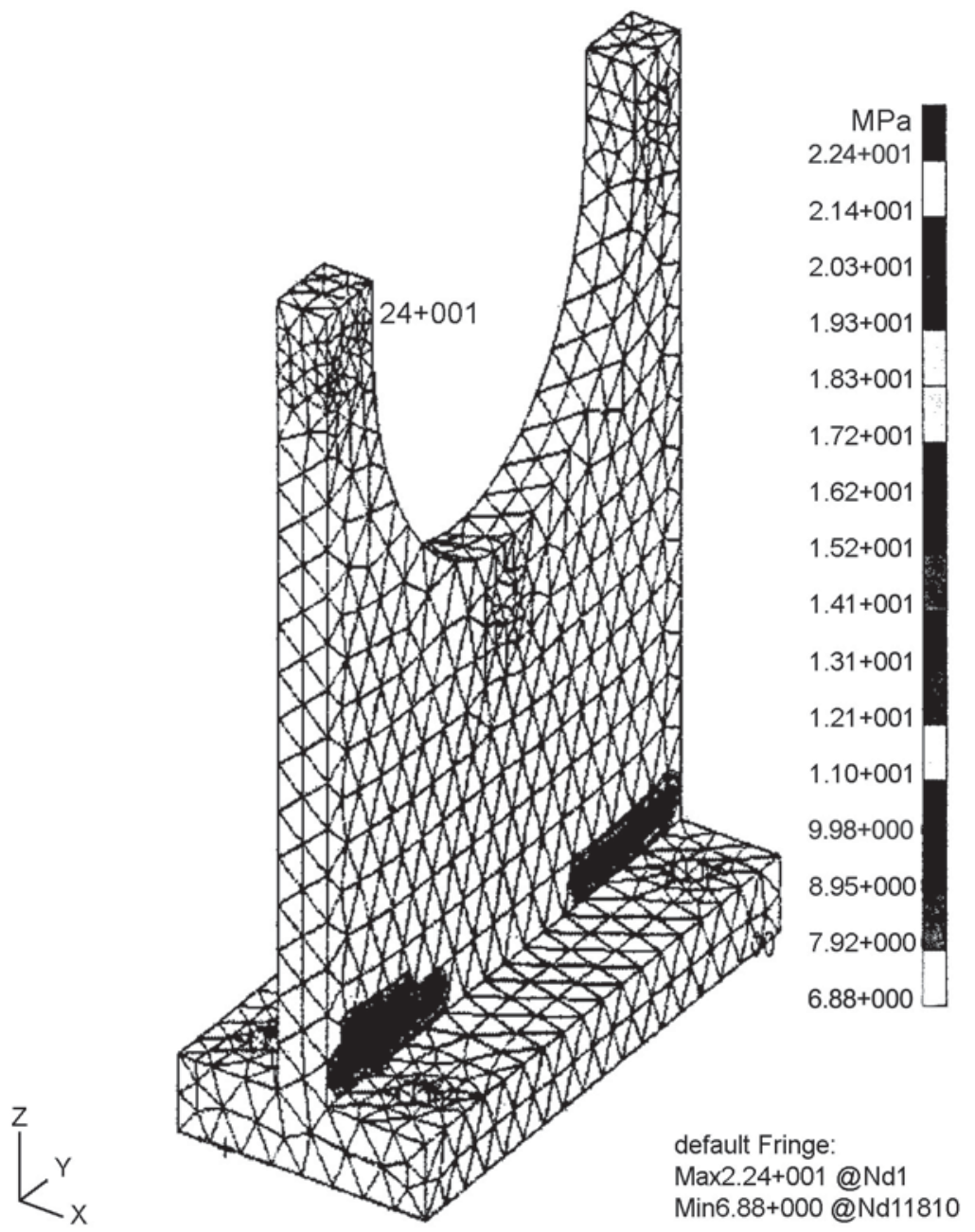

FIGURE 14. Life contour plot of log life

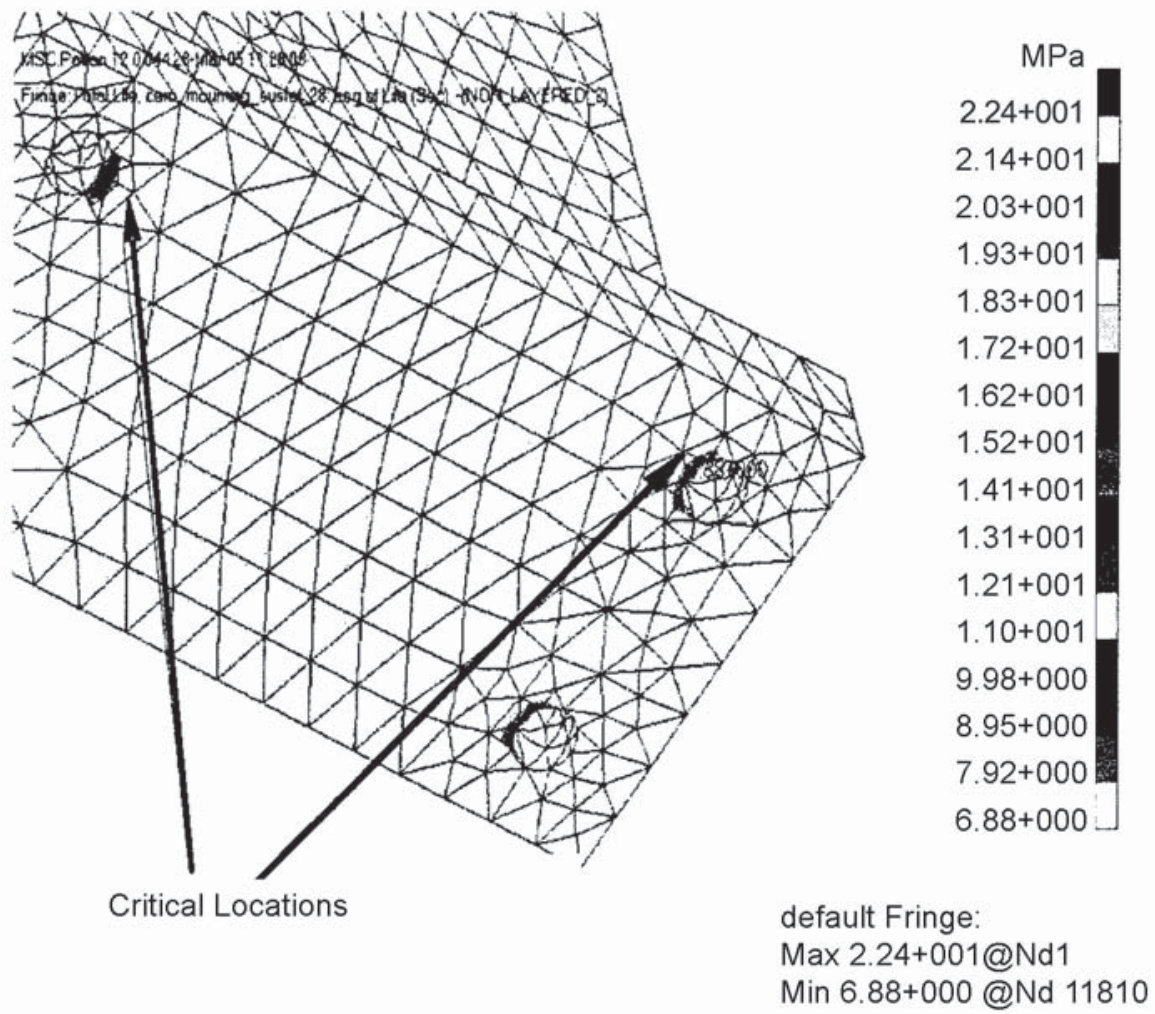

FIGURE 15. Critical locations of mounting 
can be seen that the predicted fatigue life at most critical location near the bolt hole edge (node 11810) is 106.88 seconds when using SAE 1045-450-QT material and Goodman mean stress correction method. The fatigue life is in terms of seconds using the variable amplitude SAESUS loading. The fatigue equivalent unit is 3000 cpm (cycle per min) of time history. The critical locations are shown in Figure 15 when using the SAESUS loading histories. It is found that bolt edge is the most critical positions among the mounting.

Most realistic service situations involve nonzero mean stresses. It is, therefore, very important to know the influence that mean stress has on the fatigue process so that the fully-reversed (zero mean stress) laboratory data are usefully employed in the assessment of real situations. Four types of mean stress correction method are considered in this study i.e.Goodman and Gerber correction methods for stress-life approach, and SWT and Morrow methods for strain-life approach.The predicted fatigue life at most critical location (node 11810) using different loading histories are tabulated in Tables 2 and 3, respectively, using different materials and approaches.

It is difficult to categorically select one procedure in the preference to the other. However, in Table 2, it can be seen that when

TABLE 2. Predicted fatigue life using stress-life approach

\begin{tabular}{ccccccc}
\hline \multirow{2}{*}{$\begin{array}{c}\text { Loading } \\
\text { Conditions }\end{array}$} & \multicolumn{3}{c}{ SAE1045-450-QT } & \multicolumn{3}{c}{ SAE 1045-595-QT } \\
\cline { 2 - 7 } & Gerber & Goodman & No Mean & Gerber & Goodman & No Mean \\
\cline { 2 - 7 } & 42.66 & 13.49 & 20.89 & 85.6 & 38.8 & 53.2 \\
SAETRN & 5.62 & 7.59 & 4.37 & 430 & 765 & 319 \\
SAESUS & 3.83 & 4.76 & 4.22 & 45.5 & 53.6 & 48.7 \\
SAEBRAKT & & & & &
\end{tabular}

TABLE 3. Predicted fatigue life using strain-life approach

\begin{tabular}{ccccccc}
\hline \multirow{2}{*}{$\begin{array}{c}\text { Loading } \\
\text { Conditions }\end{array}$} & \multicolumn{4}{c}{ SAE 1045-450-QT } & \multicolumn{3}{c}{ SAE 1045-595-QT } \\
\cline { 2 - 7 } & SWT & Morrow & No Mean & SWT & Morrow & No Mean \\
\hline SAETRN & 408 & 452 & 851 & 554 & 706 & 936 \\
SAESUS & 527 & 452 & 348 & 719 & 573 & 371 \\
SAEBRAKT & 92.7 & 86.5 & 78.3 & 103.8 & 98.7 & 92.0 \\
\hline
\end{tabular}

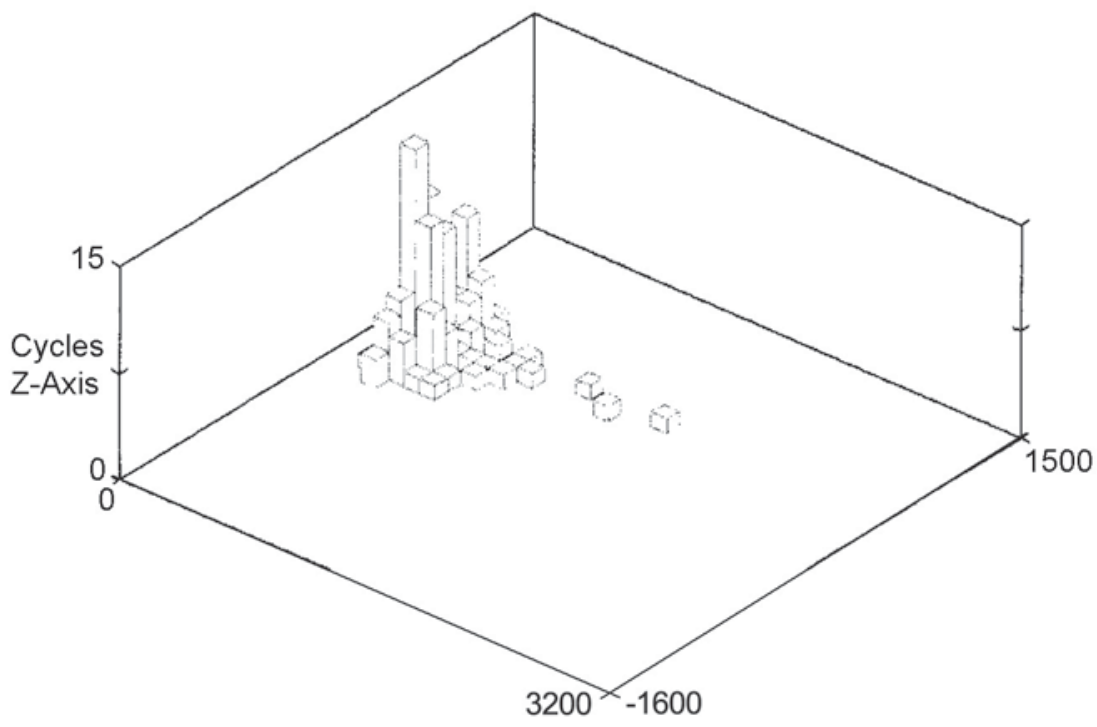

FIGURE 16. Rainflow cycle counting histogram at the critical location (node 11810) using the SAESUS data set 


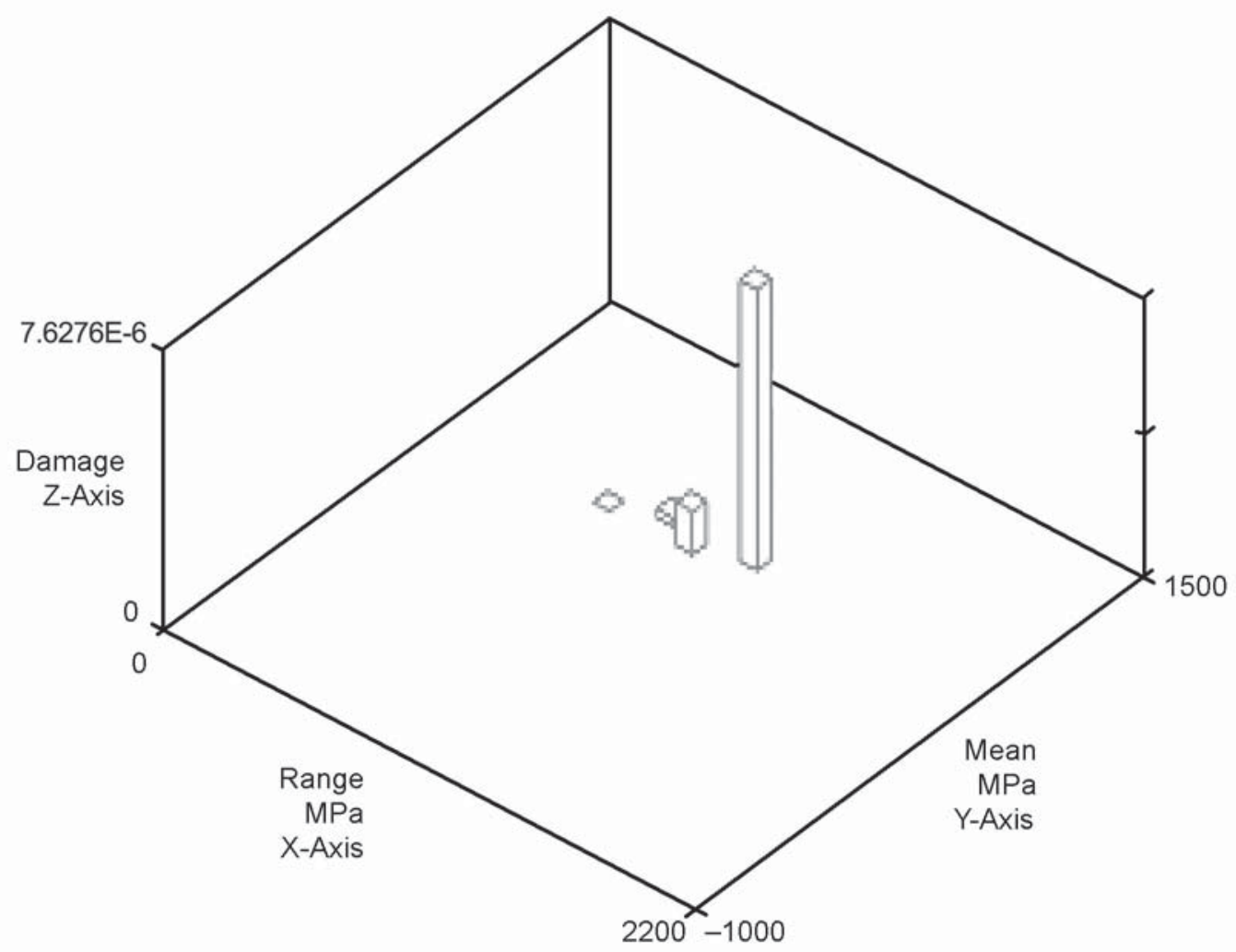

FIGURE 17. Damage Histogram at the critical location (node 11810) using the SAESUS data set

using the loading sequences are predominantly tensile in nature, the Goodman approach is more conservative. In the case where the loading is predominantly compressive, particularly for wholly compressive cycles, the no correction can be used to provide more realistic life estimates and Gerber mean stress correction has been found to give conservative when the time histories predominantly zero mean.

From Table 3, it is also seen that the two mean stress methods, SWT and Morrow give lives less than that achieved using no mean stress correction with the SWT method being the most conservative for loading sequences

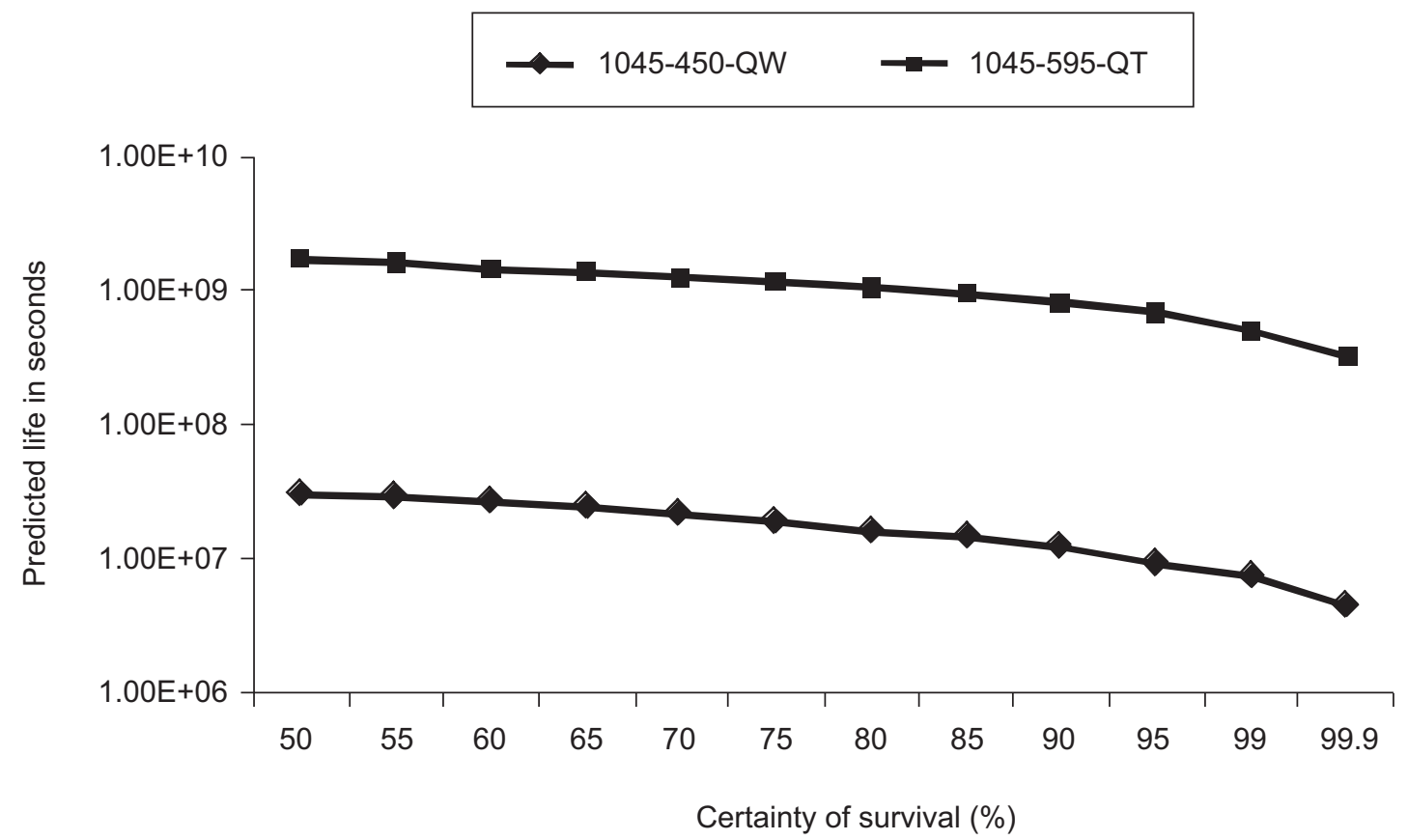

FIGURE 18. Effect of probabilistic nature of fatigue 
which are predominantly tensile in nature. In the case where the loading is predominantly compressive (SAESUS), particularly for wholly compressive cycles SWT and Morrow's methods have been found higher lives than no mean stress correction. When using the time history has a roughly zero mean (SAEBRAKT) then all three methods have been given approximately the same results. It can also be seen that SAE 1045-595-QT is consistently higher life than SAE 1045-450-QT for all loading conditions.

The Three-dimensional cycle histogram and corresponding damage histogram for materials SAE 1045-450-QT using SAESUS loading histories is shown in Figures 16 and 17, respectively. Figure 16 shows the results of the rainflow cycle count for the critical location on the component. It can be seen that a lot of cycles with a low stress range and fewer with a high range. The height of each tower represents the number of cycles at that particular stress range and mean. Each tower is used to obtain damage on the S-N curve and damage is summed over all towers. Figure 17 shows the lower stress ranges produced zero damage. It is also showed that the high stress ranges were found to give the most of the damage and a fairly wide damage distribution at the higher ranges which means that it cannot point to a single event causing damage.

Now we have investigated how the probabilistic nature depends on the fatigue life. It can be seen that 1045-595-QT is the higher strength steel, gives a much higher life prediction (Tables 2 and 3) for all mean stress corrections. This means 1045-595-QT is a better material to use. It is also observed at the $S-N$ curve as shown in Figure 6 . Figure 18 shows the effect of probabilistic nature of fatigue using the SAESUS data set for stress-life approach. From the Figure 15, it can be seen that when increases the design criterion up to 99.9 (certainty of survival 99.9\%) then the life decreases as compared to lower certainty of survival. This is due to the probabilistic nature of fatigue and the scatter associated with the $S-N$ curves themselves. The material parameters associated with $S-N$ curves take this into consideration with the standard error of $\log (\mathrm{N})$ (SE) determined by the regression analysis of the raw data. It is recommended that 99.9 (99.9\% certainty of survival) as the design criterion. The larger the scatter in the original $S$ -
$N$ data that makes up the curve, the less certain will be of survival. For both cases, it can be seen that $99.9 \%$ certainty of survival is obtained more conservative results and also determined that SAE 1045-595-QT was a better material at all lives based on the $S-N$ curves. This is due to the probabilistic nature of $S-N$ curves where the scatter in the S-N data for SAE 1045-595-QT is much more variable than for SAE 1045-450-QT.

\section{CONCLUSION}

A computational numerical model for the fatigue life assessment for mounting of the linear generator engine is presented in this paper. Through the study, several conclusions can be drawn with regard to the fatigue life of a component when subjected to complex variable amplitude loading conditions. The fatigue damage estimated based on the Palmgren-Miner rule is non-conservative and SWT correction and Morrow's damage rule can be applied to improve the estimation. It can be concluded that the influence of mean stress correction is different for compressive and tensile mean stress. Failure appears to be more sensitive to tensile mean stress, than compressive mean stress for total life approach. It is also concluded for strain-life approach that when the loading is predominantly tensile in nature, SWT approach is more sensitive and is therefore recommended. However, when the loading is compressive, the Morrow correction can be used more realistic life estimates. Therefore, it can be used an efficient and reliable means for the sign-off of durability of a prototype engine with actual service environments in the early-developing stage. It can be also seen that SAE 1045-595-QT is consistently higher life than SAE 1045-450-QT for all cases.

\section{ACKNOWLEDGEMENTS}

The authors would like to thank the Department of Mechanical and Materials Engineering, Faculty of Engineering, Universiti Kebangsaan Malaysia. The authors are grateful to Malaysia Government especially Ministry of Science, Technology and Innovation (MOSTI) under IRPA project (IRPA project no: 03-02-02-0056 PR0025/04-03) for providing financial support. 


\section{REFERENCES}

Aichlmayr, H.T.2002. Design consideration, modeling, and analysis of micro-homogeneous charge ignition combustion free-piston engine, $\mathrm{PhD}$ Dissertation, University of Minnesota, USA.

Arshad, W.M., Sadarangani, C., Bäckström, T. \& Thelin, P. 2002a. Finding an appropriate electrical machine for a free piston engine generator. Proc. of the $19^{\text {th }}$ International Battery, Hybrid and Fuelcell Electrical Vehicle Symposium (EVS-19), pp. 427-437.

Arshad, W.M., Bäckström, T., Thelin, P. \& Sadarangani, C. 2002b. Integrated free piston generators: An overview. Proc. of the Nordic Workshop on Power and Industrial Electronics, NORPIE-02, pp. 1-7.

Arshad, W.M., Bäckström, T., \& Sadarangani, C. 2002c. Evaluation of different electrical machine possibilities for an integrated free-piston generator. Proc. of the $19^{\text {th }}$ International Battery, Hybrid and Fuel-cell Electrical Vehicle Symposium (EVS-19), pp.367-375.

Arshad, W.M., Thelin, P. Bäckström, T.\& Sadarangani, C. 2003. Alternative electrical machine solutions for a free piston generator. Proc. of the $6^{\text {th }}$ International Power Engineering Conference, pp.329-334.

Arshad, W.M., Thelin, P. Bäckström, T.\& Sadarangani, C. 2004. Use of transverse flux machines in a free piston generator. IEEE Transactions on Industry Applications 40(4): 1092-1100.

Basquin, O.H. 1910.The exponential law of endurance tests. Proc. of the ASTM 10:625-630.

Berlinger, W.G., Moser, W.E., Opris, C.N., Wark, C.G. \& Weiss, L.W. 2004. Piston assembly for use in a free piston internal combustion engine. United States Patent. Patent No.6694930, pp. 1-10.

Blarigan, P.V. 2000. Advanced internal combustion engine research. Proc. of the 2000 DOE Hydrogen Program Review: NREL/CP-570-28890, pp. 1-19.

Boardman, B.E. 1982. Crack initiation fatigue - data analysis, treats and estimation. SAE Paper 820682.

Coffin L.F. Jr. 1964. A study of the effects of cyclic thermal stresses on a ductile metal.Transactions ASME 76:931-950.

Conle, F.A. \& Chu, C.C. 1997. Fatigue analysis and vehicular structures. International Journal of Fatigue 19(1): S317-323.

Cosic, A., Lindbäck, J., Arsha, W.M., Leksell, M., Thelin, P. \& Nordlund,E. 2003. Application of a free piston generator in a series hybrid vehicles. Proc of the $4^{\text {th }}$ International Symposium on Linear Drives for Industrial Applications (LDIA 2003), pp. 541-544.

Dhar, M. \& Dochat, G. 1989. Free piston space Stirling technology program. Proc. of the $24^{\text {th }}$ Intersociety
Energy Conversion Engineering Conference (IECEC-1989) 2:849-854.

Famouri, P., Cawthrne, W.R., Clark N., Nandhumar, S., Atkinson, C., Atkinson, R., McDaniel, T. \& Petreanu, S. 1999. Design and testing of a novel linear alternator and engine system for remote electrical power generator. Proceedings of the IEEE Power Engineering Society Winter Meeting 1999, pp. 108-112.

Goertz, M. \& Peng, L. 2000. Free piston engine and its application and optimization. SAE World Congress, paper no. 2000-01-0996, pp. 1-10.

Gray, Jr. C.L. 2003. Fully controlled free piston engine. United States Patent. Patent No. 6652247, pp. $1-22$.

Hofbauer, I.P., Peng, L., Tusinean, A. \& Fuqua, K. 2005. Air scavenging for an opposed piston opposed cylinder free piston engine. United States Patent. Patent No.6941904, pp. 1-29.

Juvinall, R.C. \& Marshek, K.M. 1991. Fundamentals of Machine Component Design. New York : John Wiley and sons.

Manson, S.S. 1953. Behaviour of materials under conditions of thermal stress. Heat Transfer Symposium, University of Michigan Engineering Research Institute, pp. 9-75.

Matsuishi, M. \& Endo, T. 1968. Fatigue of metals subjected to varying stress. Presented to JSME,

Miner, M.A. 1945. Cumulative damage in fatigue. Journal of Applied Mechanics 12:159-164.

Morrow, J. 1968. Fatigue Design Handbook: Advances in Engineering, pp. 21-29. Warendale, PA: SAE, Section 3.2.

Palmgren, A. 1924. Durability of ball bearings. ZVDI 68(14):339-341.

Savaidis, G. 2001. Analysis of fatigue behaviour of a vehicle Axle Steering arm based on local stresses and strains. Material wissenschaft und Werkstoff technik 32(4): 362-68.

Schaeffer, R. 2005. Free piston engine. United States Patent. Patent No.6931845, pp. 1-15.

Smith, K.N.,Watson, P.\&Topper,T.H.1970. A stress-strain functions for the fatigue on materials. Journal of Materials 5(4): 767-78.

Tucker, L. \& Bussa, S. 1997. The SAE cumulative fatigue damage test program: fatigue under complex loading. $S A E$, pp. 3-14.

Wöhler, A. 1867.Wöhler's Experiment on the strength of metals. Engineering 4:160-161.

Wood, J.G. 2005. Controlled reducing excessive amplitude of oscillation of free piston engine. United States Patent. Patent No. 6920967, pp. $1-26$. 
Zhang, X., Katzberg, J., Cooke, B.\& Kos, J. 1997. Modeling and simulation of a hybrid engine. Proc. of the IEEE WESCANEX 97: Communications, Power and Computing, pp. 286-291.
Zoroufi, M.\& Fatemi, A. 2004. Fatigue life comparisons of competing manufacturing processes: A case study of steering knuckle. SAE International. Paper No. 2004-01-0628 